\section{Natural and Synthetic Bradykinin}

SINCE the isolation of natural bradykinin by Elliott, Lewis and Horton ${ }^{1}$, a nonapeptide has been synthesized ${ }^{2,3}$ and its structure agrees with that proposed ${ }^{4}$ for the natural product. The structure is as follows: Arg.Pro.Pro.Gly.Phe.Ser.Pro.Phe.Arg.

The reported pharmacological properties of the synthetic bradykinin ${ }^{5,6}$ appeared to be similar to those found with the natural product? . However, in order to establish the fact that the synthetic and the natural substances are the same, it was necessary to make a direct quantitative comparison of their pharmacological actions.

Table 1. Ratio of ACtivity OF NATURAL to SYNTHETIC BRADYKININ

\begin{tabular}{|c|c|}
\hline Biological activity and preparation & Natural/synthetic \\
\hline $\begin{array}{l}\text { Smooth muscle contracting activity } \\
\text { Guinea pig ileum } \\
\text { Rabbit duodeaum } \\
\text { Rat uterus } \\
\text { Smooth muscle relaxing activity } \\
\text { Rat duodenum } \\
\text { Rat colon } \\
\text { Vasodilator activity } \\
\text { Human forearm* } \\
\text { Cat hind limb } \\
\text { Depressor activity } \\
\text { Cat blond pressure } \\
\text { Increased capillary permeability } \\
\text { Guinea pig skin } \\
\text { Rabbit skin } \\
\text { Pain production } \\
\text { Human blister base } \uparrow\end{array}$ & $\begin{array}{l}1 \cdot 0,0 \cdot 8,1 \cdot 0,1 \cdot 1 \\
0 \cdot 6,0 \cdot 8,1 \cdot 0 \\
1 \cdot 4,0 \cdot 6,1 \cdot 0,1 \cdot 0 \\
0 \cdot 8,1 \cdot 4,1 \cdot 1,0 \cdot 9 \\
1 \cdot 4,0 \cdot 7,0 \cdot 8,0 \cdot 8 \\
0 \cdot 7,1 \cdot 0 \\
1 \cdot 0,1 \cdot 0,0 \cdot 9,1 \cdot 0 \\
1 \cdot 0,0 \cdot 8,0 \cdot 9 \\
1 \cdot 0,1 \cdot 0,0 \cdot 9,1 \cdot 0,1 \cdot 0,0 \cdot 9 \\
1 \cdot 1,1 \cdot 0,0 \cdot 9,1 \cdot 0,0 \cdot 9,0 \cdot 8 \\
1 \cdot 0,1 \cdot 0,1 \cdot 0,1 \cdot 0\end{array}$ \\
\hline
\end{tabular}

Each numeral represents the result of one experiment. The numerals in bold type are the result of comparison with synthetic bradykinin made by Parke, Dayis (which was 80 per cent pure), the remainder with that made by Sandoz (which contained $35 \mu \mathrm{gm} . / \mathrm{ml}$.)

* From Fox, Goldsmith, Kidd and Lewis (ref. 8). threshold dose of each sample was of the same order, that is, $10^{-7} \mathrm{gm}$./1.

The pure natural bradykinin of Elliott et al. was compared with two samples of synthetic bradykininone made by Sandoz, Ltd., and the other by Parke, Davis and Co.- on eleven different biological prepara. tions. In Table 1, the ratio of natural bradykinin to synthetic bradykinin is given for the activity on these eleven preparations, and in Fig. 1 the method of obtaining these ratios is illustrated for the vasodilator activity by comparing the responses to a range of doses varying between $0.5 \mu \mathrm{gm}$. and $0.02 \mu \mathrm{gm}$.

Within the limits of experimental error the sensitivity of all eleven preparations to both natural and synthetic bradykinin was the same, proving that the natural and the synthetic bradykinin are identical.

G. P. LEwIS

National Institute for Medical Research,

The Ridgeway, Mill Hill, London, N.W.7.

${ }^{2}$ Elliott, D. F., Lewis, G. P., and Horton, E. W., Biochem. J., 74, 15 P (1960).

${ }^{3}$ Boissonnas, R. A., Guttmann, St., Jaquenoud, P.-A., Konzett, H., and Stürmer, E., Experientia, 16, 326 (1960).

3 Nicolaides, E. D., and De Wald, H. A., J. Org. Chem. (in preparation). ${ }^{4}$ Ellintt, D. F., Lewis, G. P., and Horton, E. W., Bioehem. Biophys. Res. Comm., 3, 87 (1960).

${ }^{5}$ Konzett, H., and Boissonnas, R. A., Experientia, 16, 456 (1960).

- Konzett, H., and Stürmer, E., Brit. J. Pharmacol (in the press).

2 glliott, 473 (1960).

s Fox, R. H., Goldsmith, R., Kldd, D. J., and Lewis, G. P., J. Physiol. (in preparation).

\section{Direct Comparisons of the Synthetic Nonapeptide with Trypsin Bradykin:n}

Is April 1960, Elliott, Lewis and Horton ${ }^{1}$ proposed an octapeptide structure for bradykinin. This was synthesized and found inactive by three independent groups of workers ${ }^{2-4}$. After discussion between Boissonnas and Elliott ${ }^{5}$, Boissonnas, Guttmann, Jaquenoud, Konzett and Stürmer ${ }^{3}$ described th $\ni$ nonapeptide L-arginyl-L-prolyl-L-prolyl-glycyl-L-phenylalanyl-L-seryl-L-prolyl-L-phenylalanyl-L-arginine, with properties resembling those of bradykinin. Elliott, Lewis and Horton ${ }^{5}$ have coneluded on chemical grounds that trypsin bradykinin has the structure of this nonapeptide, and Konzett and Boissonnas ${ }^{8}$ have recently published biological evidence supporting the view that this peptide is identical with bradykinin.

The present work aimed at comparing directly on several biological preparations the synthetic nonapeptide with bradykinin to provide further evidence bearing on the question whether the two substances are identical. We used a specimen of the nonapeptide synthesized by Nicolaides and De Wald ${ }^{7}$ and specimens of highly purified trypsin bradykinin, 85 and 30 per cent pure) prepared by Elliott, Lowis and Horton $^{8}$. In comparisons on the guinea pig ileum we also used a crude isolate of bradykinin $(0.05$ per cent pure) prepared by Lockhart and Jones by

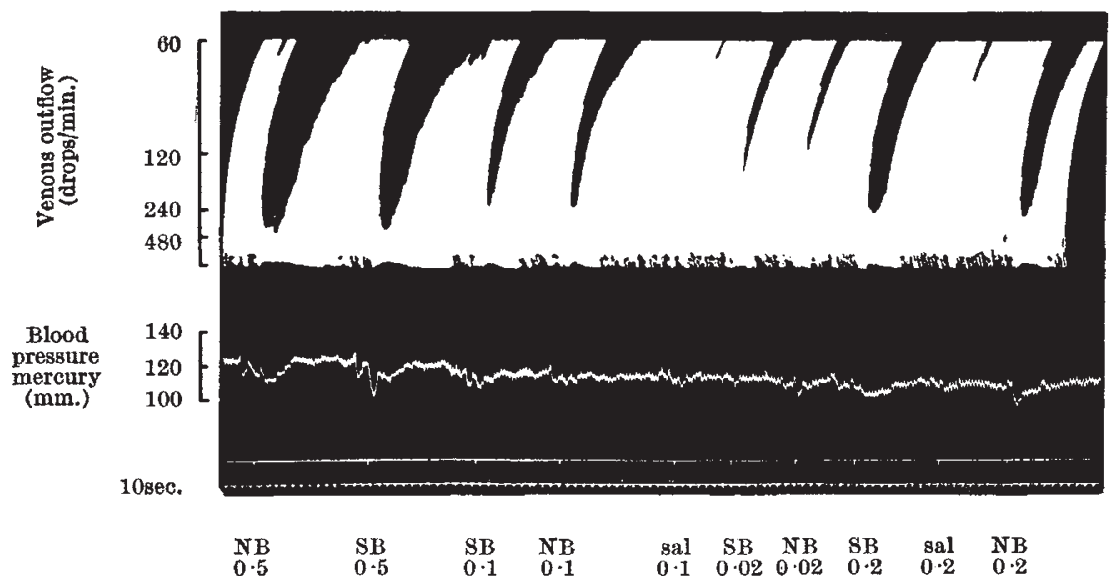

Fig. 1. Cat, $2 \cdot 5 \mathrm{kgm}$. anæsthetized with chloralose $60 \mathrm{mgm}$. $/ \mathrm{kgm}$. Upper tracing record of venous outflow from the hind limb. Lower tracing arterial blood pressure. Close arterial injections of natural bradykinin (NB) and synthetic bradykinin (SB), $0.5,0.1,0.02$ and $0.2 \mu \mathrm{gm} .$, and of saline (sal) $0.1 \mathrm{ml}$. and $0.2 \mathrm{ml}$. Comparison of
in this experiment gave a ratio of 1.0 